\title{
Penerapan Metode Resitasi Untuk Meningkatkan Aktivitas dan Hasil Belajar Siswa Pada Mata Pelajaran Ekonomi Materi Pendapatan Nasional (Studi Kasus Pada Mata Pelajaran Ekonomi Kompetensi Dasar Pendapatan Nasional Kelas XI IPS 2 di MAN 2 Jember The Implementation of Recitation Method to Improve Activities and Students' Learning Outcome of Economics in National Income (A Case Study on The Students of XI of Social Science At MAN 2 Jember of National Income In Economics
}

\author{
Nuri Nurma Yunita, Sri Wahyuni, Pudjo Suharso \\ Program Studi Pendidikan Ekonomi, Fakultas Keguruan dan Ilmu Pendidikan, Universitas Jember (UNEJ) \\ Jln. Kalimantan 37, Jember 68121 \\ E-mail: sri280557@yahoo.co.id
}

\section{Abstrak}

Penelitian ini bertujuan untuk meningkatkan aktivitas dan hasil belajar siswa kelas XI IPS 2 MAN 2 Jember tahun ajaran 2016/2017 pada mata pelajaran ekonomi materi pendapatan nasional melalui penerapan metode resitasi. Penelitian ini merupakan penelitian tindakan kelas yang dirancang dalam dua siklus dan masing-masing siklus terdiri dari empat tahapan yaitu perencanaan, tindakan, observasi, dan refleksi. Subjek penelitian ini siswa kelas XI IPS 2 yang berjumlah 28 siswa. Metode pengumpulan data yang digunakan dalam penelitian ini yaitu observasi, wawancara, tugas ,dan dokumen. Analisis data aktivitas siswa diperoleh dari hasil observasi pada saat pelaksanaan tindakan perbaikan. Analisis hasil belajar siswa diperoleh dari rata-rata nilai tugas siswa. Hasil penelitian ini menyatakan bahwa penerapan metode resitasi dalam proses pembelajaran dapat meningkatkan aktivitas belajar siswa dari kriteria rendah dengan ketuntasan 39\% menjadi kriteria sedang dengan ketuntasan 59\% pada siklus I. Pada siklus II meningkat kembali dari ketuntasan 59\% dengan kriteria sedang menjadi $67 \%$ dengan kriteria tinggi. Begitu pula pada hasil belajar siswa juga mengalami peningkatan, rata-rata nilai siswa sebelum tindakan sebesar 57,4 setelah pelaksanaan siklus I meningkat menjadi 77,21 dengan ketuntasan klasikal 70.8 \%. Pada siklus II meningkat kembali menjadi 79,71 dengan ketuntasan klasikal 96,15. Berdasarkan analisis data yang dilakukan dapat diketahui bahwa dengan menerapkan metode resitasi dapat meningkatkan aktivitas dan hasil belajar siswa.

Kata Kunci: Metode Resitasi, aktivitas dan hasil belajar siswa

\section{Abstract}

This research in order to improve the XI IPS 2 students' learning actities and their achievement at MAN 2 Jember of academic year 2016/2017 in national income of economic by implementation of recitation method. This research is a classroom action research conducted in two cycles and each cycle consists of four phases that was planning, implementing the action, observation, and reflection. The subject of this research is the students of XI IPS 2 consist of 28 students. The data collection method that is used in this research are observation, interview, and documents. The data analysis of the students' activity obtained the result observation during implementing the action, remedial. Analysis of the students learning outcomes obtained from the average of the students' score. The result of this research showed that the implementation the recitation method in the teaching learning process could improve the students' learning activities and their achievement from 39\% lowest criteria of standard requirement score to $59 \%$ medium criteria of requirement score in the first cycle and $67 \%$ highest criteria of standard requirement score in the second cycle. Although the result of the students' achievement increase from 57.4 the average of the students' achievement in the cycle I to 77.21 and the classical completeness is $70.8 \%$, in the second cycle increase become 79.71 and the classical completeness is 96.15 . Based on the analysis data it can be concluded that by applying the recitation method could improve the students' active participation and their achievement.

\section{Keywords : Recitation Method, Activities And Student Learning Outcome}

\section{Pendahuluan}

Tujuan pembelajaran ekonomi pada materi pendapatan nasional menekankan pada pemahaman siswa. Pemahaman siswa dapat diperoleh selain dari penjelasan guru, juga dapat diperoleh dengan mengerjakan tugas yang diberikan oleh guru. Aktivitas belajar bukanlah menghafal sejumlah fakta atau informasi. Belajar adalah berbuat, memperoleh pengalaman tertentu sesuai dengan tujuan 
yang diharapkan, yang tidak terbatas aktivitas fisik saja tetapi meliputi aktivitas mental juga.

Penelitian dilakukan di MAN 2 Jember karena peneliti melihat adanya permasalahan pembelajaran yang dihadapi oleh guru mata pelajaran ekonomi kelas XI untuk segera diselesaikan dan adanya dukungan dari pihak sekolah serta kemauan guru untuk mengatasi permasalahan pembelajaran dengan melakukan perbaikan. Guru merekomendasikan untuk melakukan perbaikan di kelas XI IPS 2, karena menurut guru dan menurut data pembelajaran yang dimiliki oleh guru dari dua kelas yang dipegang oleh guru tersebut, kelas XI IPS 2 memiliki aktivitas dan hasil belajar yang paling rendah.

Berikut hasil observasi aktivitas belajar yang dilakukan di kelas XI IPS 2 MAN 2 Jember pada mata pelajaran ekonomi saat kegiatan pembelajaran berlangsung: Tabel 1. Aktivitas belajar siswa kelas XI IPS 1 dan XI IPS 2 pada mata pelajaran ekonomi

\begin{tabular}{|l|c|c|c|c|}
\hline $\begin{array}{l}\text { N } \\
\text { o }\end{array}$ & Kelas & $\begin{array}{c}\text { Jumlah } \\
\text { Siswa }\end{array}$ & $\begin{array}{c}\text { \% Aktivitas } \\
\text { Belajar }\end{array}$ & Kriteria \\
\hline 1. & XI IPS 1 & 34 & $54 \%$ & Sedang \\
\hline 2. & XI IPS 2 & 28 & $39.00 \%$ & Rendah \\
\hline
\end{tabular}

Sumber: data hasil observasi aktivitas belajar

Berdasarkan tabel diatas maka aktivitas belajar siswa kelas XI IPS 2 sebesar 39\% yang masuk pada kriteria rendah (kriteria 21\% - 40\%). Menurut Paul B. Diedrich dalam Hamalik [2], membagi aktivitas belajar siswa ke dalam 8 kelompok yaitu kegiatan visual seperti membaca, kegiatan lisan seperti mengemukakan pendapat, kegiatan mendengarkan seperti mendengarkan penyajian bahan, kegiatan menulis seperti mengerjakan tugas dan tes, kegiatan menggambar, kegiatan metric seperti percobaan, kegiatan mental seperti menganalisis, dan kegiatan emosional seperti membedakan.

Aktivitas belajar yang rendah ini menyebabkan hasil belajar siswa yang rendah juga, hal ini dibuktikan dengan data hasil belajar siswa yang diperoleh dari guru berupa nilai ulangan harian siswa dari 28 siswa yang mengikuti ulangan hanya 1 orang yang memperoleh nilai diatas KKM sekolah yaitu 75 . Nilai rata-rata yang diperoleh hanya sebesar 57.4 kondisi ini sungguh sangat memprihatinkan bagi guru. Dimana menurut Jihad [3], untuk memperoleh hasil belajar, dilakukan evaluasi atau penilaian yang merupakan tindak lanjut atau cara untuk mengukur tingkat penguasaan siswa. Kemajuan prestasi belajar siswa tidak saja diukur dari tingkat penguasaan ilmu pengetahuan tetapi juga sikap dan keterampilan. Dengan demikian penilaian hasil belajar siswa mencakup segala hal yang dipelajari di sekolah, baik itu pengetahuan, sikap, dan keterampilan.

Berdasarkan hal inilah, guru dengan bantuan peneliti menetapkan penerapan metode resitasi untuk mengatasi permasalahan diatas. Metode resitasi dianggap paling cocok dengan kemampuan siswa kelas XI IPS 2 MAN 2 Jember dan sesuai dengan karakteristik materi pendapatn nasional yang banyak. Menurut Roestiyah [5], metode penugasan atau resitasi yang digunakan oleh guru harus menyesuaikan dengan tujuan pembelajaran yang akan dicapai, sehingga siswa dapat memahami dan melaksanakan tugas yang diberikan dengan penuh tanggung jawab. Tugas yang diberikan dalam bentuk daftar sejumlah pertanyaan, satu perintah diskusi, mancari uraian pada buku mata pelajaran. Pada akhirnya siswa akan lebih bertanggung jawab dalam menyelasaikan tugas yang diberikan. Menurut Djamarah dan Zain [1], metode resitasi merupakan metode dimana guru memberikan tugas agar siswa belajar yang tidak hanya didalam kelas, namun dapat juga di halaman sekolah, di laboratorium, di perpustakaan ataupun di rumah. Resitasi merangsang anak untuk aktif belajar, baik secara individual maupun secara kelompok.

Berdasarkan latar belakang diatas peneliti tertarik untuk melakukan penelitian tindakan kelas yang berjudul "Penerapan Metode Resitasi Untuk Meningkatkan Aktivitas dan Hasil Belajar Siswa Pada Mata Pelajaran Ekonomi Materi Pendapatan Nasional (Studi Kasus Pada Mata Pelajaran Ekonomi Kompetensi Dasar Pendapatan Nasional Kelas XI IPS 2 di MAN 2 Jember Tahun Ajaran 2016/2017)".

\section{Metode Penelitian}

Penelitian ini dilakukan di kelas XI IPS 2 MAN 2 Jember yang dilaksanakan pada semester ganjil tahun ajaran 2016/2017 pada mata pelajaran ekonomi materi pendapatan nasional dengan subjek penelitia siswa kelas XI IPS 2 yang berjumlah 28 siswa yang terdiri dari 13 siswa laki-laki dan 15 siswa perempuan. Jenis penelitian ini adalah penelitian tindakan kelas dengan menggunakan model berbentuk spiral oleh Hopkins (1985) sebagai

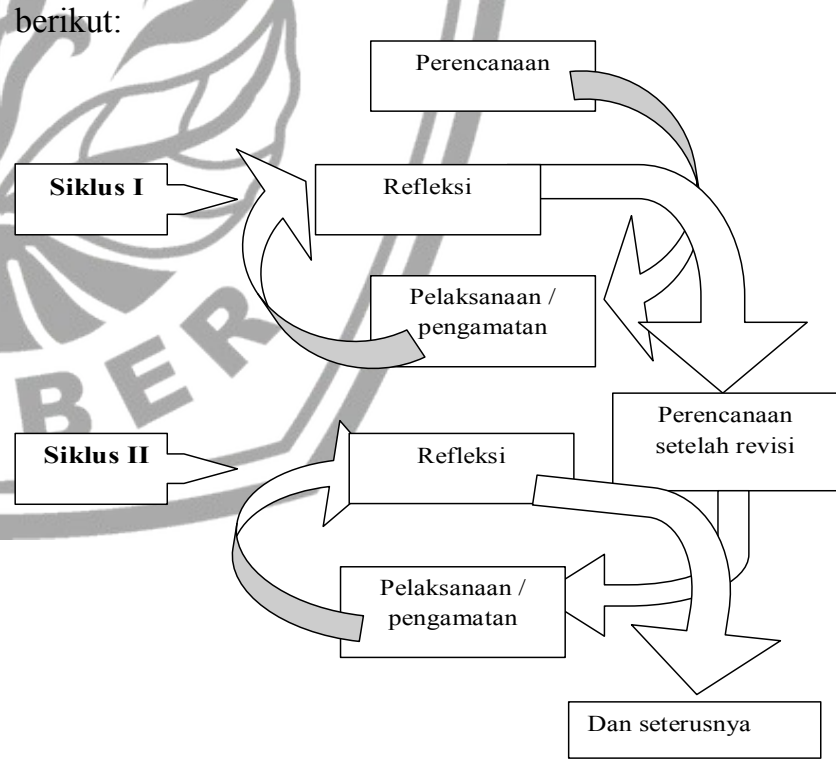

Gambar 1. Model penelitian tindakan kelas oleh Hopkins (Muslich, 2011)

Berdasarkan gambar model penelitian di atas, penelitian ini menggunakan skema 4 spiral yang terdiri dari dua siklus, setiap siklus terdiri dari empat fase yaitu rencana awal atau rancangan, tindakan, observasi, dan refleksi. Setiap siklus terdiri dari 2 kali pertemuan dimana setiap pertemuan siswa diberikan satu tugas. Pelaksanaan pada siklus ke 2 sama dengan siklus 1, namun penyempurnaan langkah-langkah yang belum sepenuhnya dilaksanakan pada siklus 1 dan sebagai pemantapan. 
Penelitian diawali dengan tindakan pendahuluan dan selanjutnya pelaksanaan siklus 1 dan siklus 2 yang terdiri atas empat tahap sebagai berikut:

a. Tindakan pendahuluan

- Meminta izin observasi dan penelitian kepada kepala, waka kurikulum serta guru mata pelajaran ekonomi MAN 2 Jember.Melakukan observasi awal untuk mengidentifikasi masalah yang ada dalam pembeelajaran di kelas XI IPS 1 dan XI IPS 2.

- Melakukan kegiatan wawancara terhadap guru mata pelajaran ekonomi untuk mengetahui permasalahan yang dihadapi dalam pembelajaran di kelas XI IPS.

- Melakukan diskusi bersama guru untuk menentukan kelas dan untuk mengatasi permasalahan yang dihadapi.

- Melakukan diskusi bersama guru mata pelajaran dalam penerapan metode resitasi.

b. Pelaksanaan siklus I

Tahap-tahap yang dilakukan pada siklus I dan siklus II penelitian ini berdasarkan pada model spiral yang telah dijelaskan sebelumnya yaitu model spiral oleh Hopkins, yang terdiri dari 4 fase yaitu :

1. Perencanaan

a. Peneliti bersama dengan guru menyusun rencana pelaksanaan pembelajaran (RPP) materi pendapatan nasional dengan menggunakan metode resitasi.

b. Peneliti bersama guru berkoordinasi menyusun tugas yang akan diberikan pada saat pelaksanaan pembelajaran dengan metode resitasi.

c. Peneliti menyiapkan instrumen penilaian yaitu lembar observasi aktivitas siswa dan menyiapkan alat dokumentasi yang digunakan dalam penelitian.

2. Tindakan

Pelaksanaan tindakan pada setiap pertemuan meliputi:

a. Pendahuluan, guru mengucapkan salam kepada dan siswa mengecek kehadiran siswa.

b. Apersepsi, menyampaikan pokok bahasan dan tujuan pembelajaran yang akan dilakukan.

c. Guru menjelaskan pelaksanaan pembelajaran dengan menggunakan metode resitasi.

d. Guru menyampaikan materi pembelajaran pada pertemuan tersebut.

e. Guru memberikan lembar tugas/ LKS yang sesuai dengan materi pembelajaran secara individu.

f. Guru memberikan waktu pada siswa untuk mengerjakan tugas tersebut secara individu dengan sebaik-baiknya, serta guru berkeliling untuk mengotrol siswa dalam mengerjakan tugas.

g. Setelah waktu yang diberikan selesai, guru meminta siswa mengumpulkan tugasnya.

h. Penutup, guru membantu siswa membuat kesimpulan, menyampaikan materi selanjutnya, dan salam.

3. Observasi

Pada tahap observasi peneliti melakukan observasi bersama 2 observer lainnya dalam melakukan melakukan penelitian aktivitas siswa pada saat proses pembelajaran berlangsung dengan menerapakan metode resitasi. Observasi dilakukan kepada guru dan siswa, observasi kepada guru bertujuan untuk mengetahui terlaksananya rencana pembelajaran yang telah disusun sebelumnya, sedangkan observasi kepada siswa bertujuan untuk melihat peningkatan aktivitas belajar siswa dengan menerapkan metode resitasi. Kegiatan observasi dilakukan dengan menggunakan lembar observasi yang telah disusun.

\section{Refleksi}

Kegiatan yang dilakukan dalam refleksi adalah mengkasi dan menganalisis rangkaian kegiatan yang telah dilakukan sebelumnya, refleksi dilakukan berdasarkan hasil observasi aktivitas belajar siswa dan mengajar guru, dan hasil nilai tugas-tugas yang dikerjakan siswa pada saat pembelajaran menggunakan metode resitasi.

Metode pengumpulan data yang digunakan adalah observasi, tugas, wawancara, dan dokumen. Kegiatan observasi aktivitas siswa dengan pemberian skor pada tiaptiap indikator yaitu mencari dan mengumpulkan data, mengerjakan tugas, dan mempertanggungjawabkan tugas. Kegiatan penilaian menggunakan numerical rating scale dimana makin tinggi skor maka semakin tinggi aktivitas belajar siswa. Data hasil observasi aktivitas belajar siswa setelah dioalah lalu dinterpretasikan ke dalam kategori aktivitas belajar siswa sebagai berikut:

Tabel 2. Pedoman kriteria aktivitas belajar siswa

\begin{tabular}{|c|c|}
\hline Persentase & Kriteria aktivitas belajar siswa \\
\hline$\geq 81 \%$ & Sangat Tinggi \\
\hline $61 \%-80 \%$ & Tinggi \\
\hline $41 \%-60 \%$ & Sedang \\
\hline $21 \%-40 \%$ & Rendah \\
\hline $0 \%-20 \%$ & Sangat Rendah \\
\hline
\end{tabular}

Sumber: Arikunto (2008)

Data hasil belajar berupa rata-rata nilai tugas, siswa dikatakan tuntas apabila mencapai nilai diatas KKM $\geq 75$ dengan ketuntasan klasikal sebesar $75 \%$.

Data dari hasil ulangan harian siswa (tes), siswa dikatakan berhasil atau tuntas apabila mencapai 75\% dari nilai yang seharusnya dicapai atau nilai maksimal. Dirumuskan sebagai berikut:

Siswa dikatakan tuntas apabila memperoleh nilai diatas $\mathrm{KKM} \geq 75$ dan persentase nilai mencapai $75 \%$ dari nilai maksimal.

- Kelas dinyatakan tuntas apabila jumlah siswa mencapai ketuntasan 75\% dari jumlah siswa di kelas XI IPS 2.

Analisis data hasil wawancara menggunakan kualitatif dengan teknik interaktif, menurut Miles dan Huberman teknik analisis ini terdiri dari tiga komponen yang saling berkaitan yaitu reduksi data, display data, kemudian penarikan kesimpulan. Reduksi data yaitu menyeleksi dan menyederhanakan data menjadi data penting, selanjutnya display data yaitu menyajikan data untuk dapat mudah dipahami dan penarikan kesimpulan yaitu memberikan penilaian atau interpretasi. Indikator keberhasilan penelitian ini apabila adanya peningkatan pada aktivitas dan hasil belajar sebagai berikut:

- Meningkatnya aktivitas belajar siswa berupa mendengarkan penjelasan guru, bertanya, mengerjakan tugas individu, sampai menjadi $\geq 61 \%$ (kriteria 
aktivitas belajar tinggi $61 \%-80 \%$ ) atau sampai pada kategori sangat tinggi yaitu $\geq 81 \%$.

- Meningkatnya hasil belajar siswa berupa nilai tugas, rata-rata nilai ulangan siswa yang semula 57,4 menjadi mencapai KKM 75 dan ketuntasan belajar siswa menjadi 75\% siswa tuntas diatas KKM (nilai 75).

\section{Hasil dan Pembahasan}

Berdasarkan hasil observasi pada saat perbaikan pembelajaran siklus I dan siklus II dengan penerapan metode resitasi dapat meningkatkan aktivitas dan hasil belajar siswa kelas XI IPS 2 MAN 2 Jember. Peningkatan pada aktivitas belajar dari siklus I ke siklus II, terjadi peningkatan pada setiap indikator sebersar $2 \%$ kecuali pada indikator mempertanggungjawabkan tugas yang mengalami kenaikan yang tinggi yaitu sebesar $23 \%$. Peningkatan ini disebabkan karena guru menerapkan metode resitasi dalam pembelajaran. Peningkatkan aktivitas belajar siswa dapat dilihat pada diagram 1. Hasil belajar siswa diperoleh dari nilai rata-rata tugas siswa, kemudian dilihat dari ketuntasan klasikal yang telah dicapai. Peningkatan nilai rata-rata tugas siswa yakni 77,21 pada siklus I menjadi 79,71 pada siklus II dan ketuntasan klasikal sebesar $70.08 \%$ pada siklus I menjadi $96.15 \%$ pada siklus II. Peningkatan hasil belajar siswa dapat dilihat pada diagram 2 .

Hasil penelitian menunjukkan bahwa hasil belajar siswa kelas XI IPS 2 MAN 2 Jember tahun ajaran 2016/2017 baik dilihat dari nilai rata-rata tugas yang diberikan selama tindakan pada mata pelajaran ekonomi kompetensi dasar pendapatan nasional telah meningkat sesuai $\mathrm{KKM} \geq 75$ dengan kriteria Baik dan aktivitas belajar siswa juga telah meningkat dari kriteria rendah menjadi tinggi, dimana rendah berarti kurang aktif menjadi aktif, merupakan bukti bahwa pendapat Djamarah dan Zain (2006:85) yang menyatakan bahwa resitais merangsang anak untuk aktif belajar, baik secara individu maupun secara kelompok, dengan demikian hipotesis penelitian telah terbukti. Dimana peneraparan metode reitasi dapat meningkatkan aktivitas dan hasil belajar siswa.

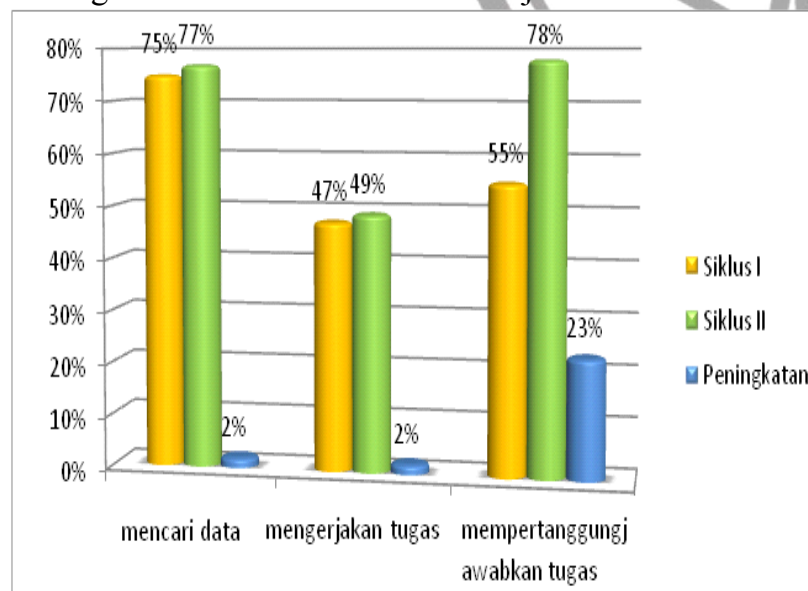

Diagram 1. Peningkatan aktivitas belajar siklus I dan II

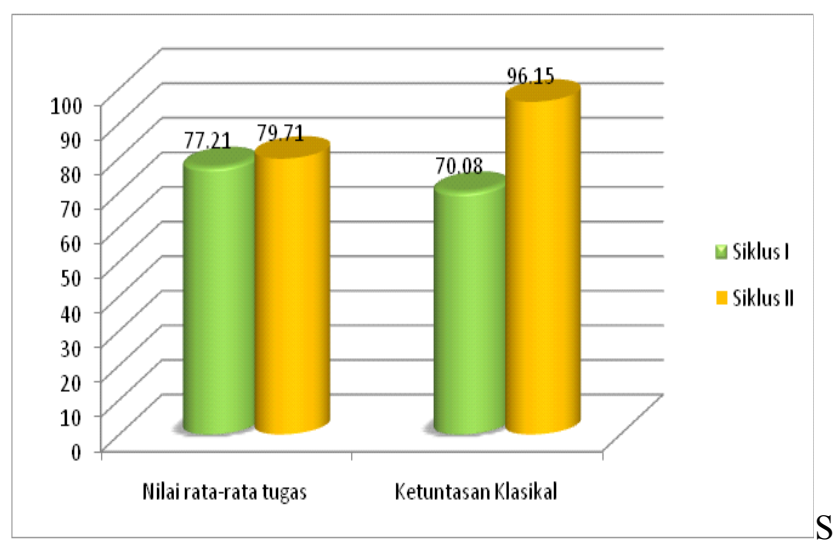

Diagram 2. Peningkatan hasil belajar siswa

Peningkatan aktivitas dapat dilihat pada saat proses pembelajaran berlangsung dengan menggunakn metode resitasi, siswa antusias dan bersemangat ketika mencari data untuk mengerjakan tugas yang diberikan, berusaha secara mandiri untuk mengerjakan tugas tanpa membuka buku dan meminta bantuan dari temannya, serta dapat mempertanggungjawabkan tugas yang telah dikerjakan dengan sangat baik dan penuh tanggung jawab. Sesuai dengan fase-fase yang ada dalam metode resitasi bahwa aktivitas siswa dapat meningkat ketika siswa diberikan tanggung jawab dan diberikan sebuah tugas secara mandiri. Hasil belajar siswa yang diperoleh dari nilai-nilai tugas yang telah dikerjakan oleh siswa, menunjukkan bahwa metode resitasi dapat mendorong siswa untuk lebih bersemangat dan bertanggung jawab dalam mengerjakan tugas yang diberikan oleh guru. Tindakan pada siklus I siswa menjadi lebih semangat dalam pembelajaran dengan metode resitasi. Terbukti dalam hasil observasi pada siklus I aktivitas siswa mencapai 59.19\% yang termasuk pada kriteria sedang atau cukup aktif. Nilai rata-rata tugas siswa pada siklus I mencapai 77.21 dan telah memenuhi KKM $\geq$ 75 , namun untuk ketuntasan klasikal hanya mencapai 70.08 dan belum memenuhi ketuntasan klasikal yang ditetapkan sekolah.

Tindakan pada siklus II dapat lebih meningkatkan aktivitas siswa karena pada siklus II ini dalam mengerjakan tugas yang diberikan lebih dituntut dengan kemampuan sendiri tanpa membuka buka dan tanpa bantuan teman, sehingga aktivitas siswa mencapai persentase $67.95 \%$ dan dalam kriteria tinggi. Hal tersebut akan membuat siswa lebihberusaha mengingat materi yang telah diajarkan dan dapat langsung mengaplikasikan dalam soal-soal yang diberikan. Tugas yang diberikan juga membuat siswa berani bertanya dengan apa yang mereka kurang pahami, selain itu tugas yang diberikan menjadikan siswa lebih bertanggung jawab dan disiplin dalam menyelesaikannya. Hasil belajar yang diperoleh dari nilai rata-rata tugas juga menunjukkan bahwa penerapan metode resitasi sangat tepat untuk menumbuhkan pemahaman siswa dalam memahami materi pembelajaran dimana pada siklus II ini rata-rata nilai tugas siswa mencapai 79.71 dan memenuhi KKM $\geq$ 75 dalam kriteria Baik. Ketuntasan klasikal meningkat lebih tinggi dibanding dengan siklus I karena tugas yang diberikan menuntut lebih pada kemampuan individu siswa, siswa dianjurkan untuk tidak membuka buka ataupun dengan bantuan teman. Hal tersebut meningkatkan 
ketuntasan klasikal sebesar 96.15\% dan telah memenuhi standard ketuntasan yang ditetapka oleh sekolah yaitu $75 \%$.

Pembahasan diatas dan didukung penelitian terdahulu oleh Arif Sandro Dermawan (2011), yang berjudul "implementasi metode resitasi untuk meningkatkan aktivitas dan hasil belajar siswa (studi kasus pada mata pelajaran ekonomi pada pokok bahasan mengklasifikasi tenaga kerja siswa kelas XI IPS 4 di SMA Negeri 3 Lumajang semester ganjil tahun ajaran 2011/2012)", bahwa penerapan metode resitasi dalam pembelajaran ekonomi materi pendapatan nasional dapat berjalan dengan baik dan dapat meningkatkan aktivitas belajar siswa sebesar $85 \%$ dan hasil belajar siswa dengan nilai rata-rata 84,62. Maka metode resitasi dapat diterapkan dalam pembelajaran ekonomi ke depan dengan materi yang yang sesuai dan dengan inovasi dan pengetahuan yang lebih baik.
[5] Roestiyah. 1998. Strategi Belajar Mengajar. Jakarta: PT. Rineka Cipta.

[6] Sudjana, Nana. 2006. Penilaian Hasil Proses Belajar Mengajar. Bandung: PT. Remaja Rosdakarya.

\section{Kesimpulan dan Saran}

Penerapan metode resitasi pada pembelajaran ekonomi materi pendapatan nasional dapat berjalan dengan baik dan efektif, hal ini dibuktikan berdasarkan hasil penelitian yang telah dibahas pada bab sebelumnya, dapat disimpulkan bahwa dengan menerapkan metode resitasi dalam pelajaran ekonomi dapat meingkatkan aktivitas siswa mulai dari mencari dan mengumpulkan data, mengerjakan tugas secara individu, serta mempertanggungjawabkan tugas dan maningkatkan hasil belajar yang diperoleh dari rata-rata nilai tugas selama proses tindakan. Peningkatan aktivitas belajar siswa diperoleh dari hasil observasi selama pembelajaran, hasil observasi menunjukkan adanya peningkatan dari siklus I ke siklus II dengan hasil $59.19 \%$ dengan kriteria sedang menjadi $67.95 \%$ dengan kriteria tinggi. Peningkatan hasil belajar siswa dapat dilihat dengan nilai rata-rata tugas dari siklus I ke siklus II, nilai rata-rata sebesar 77.21 dengan ketuntasan klasikal sebesar $70.08 \%$ meningkat menjadi 79.71 dengan ketuntasan klasikal sebesar $96.15 \%$.

Berdasarkan hasil penelitian yang telah dilakukan, maka peneliti menyarankan dalam menerapkan metode resitasi dalam proses pembelajaran pada materi yang sesuai, selain itu dalam menerapkan metode resitasi tugas yang diberikan harus sesuai dengan kemampuan masingmasing siswa agar dalam mengerjakan tugas siswa dapat mengerjakan tugas yang diberikan benar-benar dengan kemampuannya sendiri. Guru juga harus melakukan inovasi-inovasi pada tugas yang akan diberikan pada siswa.

\section{Daftar Pustaka}

[1] Djamarah, S dan Zain, A. 2006. Strategi Belajar Mengajar (Edisi Revisi). Jakarta: PT. Rineka Cipta.

[2] Dermawan, Arif Sandro. 2011. implementasi metode resitasi untuk meningkatkan aktivitas dan hasil belajar siswa (studi kasus pada mata pelajaran ekonomi pada pokok bahasan mengklasifikasi tenaga kerja siswa kelas XI IPS 4 di SMA Negeri 3 Lumajang Semester Ganjil Tahun Ajaran 2011/2012). Tidak diterbitkan. Skripsi. Universitas Jember.

[3] Jihad, A dan Haris, A. 2012. Evaluasi Pembelajaran. Yogyakarta: Multi Pressindo.

[4] Muslich, M. 2011. Melaksanakan PTK Itu Mudah. Jakarta: Bumi Aksara. 